\title{
Intramedullary Conus Medullaris Tuberculoma: A Case Report and Review of the Literature
}

\author{
Verajit Chotmongkol ${ }^{1}$, Chinadol Wanitpongpun ${ }^{1}$, Warinthorn Phuttharak ${ }^{2}$ and Sittichai Khamsai ${ }^{1, * \mathbb{D}}$ \\ 1 Department of Medicine, Faculty of Medicine, Khon Kaen University, Khon Kaen 40002, Thailand; \\ vercho@kku.ac.th (V.C.); chinwa@kku.ac.th (C.W.) \\ 2 Department of Radiology, Faculty of Medicine, Khon Kaen University, Khon Kaen 40002, Thailand; \\ pwarin@kku.ac.th \\ * Correspondence: sittikh@kku.ac.th; Tel.:+66-43-363664; Fax: +66-43-348399
}

Citation: Chotmongkol, V.;

Wanitpongpun, C.; Phuttharak, W.;

Khamsai, S. Intramedullary Conus Medullaris Tuberculoma: A Case Report and Review of the Literature. Infect. Dis. Rep. 2021, 13, 82-88. https://doi.org/10.3390/idr13010010

Received: 16 November 2020 Accepted: 14 January 2021 Published: 15 January 2021

Publisher's Note: MDPI stays neutral with regard to jurisdictional clai$\mathrm{ms}$ in published maps and institutional affiliations.

Copyright: (C) 2021 by the authors. Licensee MDPI, Basel, Switzerland. This article is an open access article distributed under the terms and conditions of the Creative Commons Attribution (CC BY) license (https:// creativecommons.org/licenses/by/ $4.0 /)$.

\begin{abstract}
Intramedullary tuberculoma (IMT) of the conus medullaris is extremely rare. We present a case of intramedullary conus medullaris tuberculoma in which the diagnosis was based on there being very high levels of adenosine deaminase (ADA) in the patient's cerebrospinal fluid (CSF) and improvement with antituberculous therapy. A 78-year-old man presented after having had a dull ache in both thighs and progressive paraparesis. The patient's medical history included diffuse large B-cell lymphoma, which had undergone remission due to chemotherapy two years earlier, and long-term, well-controlled diabetes. A chest X-ray showed no evidence of tuberculosis. The results of CSF analysis were compatible with Froin's syndrome. An initial diagnosis was made of an intramedullary tumor of the conus medullaris, based on magnetic resonance imaging (MRI). A myelotomy and multiple punch out biopsy were performed, and histopathology of the tissues revealed mild reactive gliosis. Due to the patient having high levels of CSF-ADA, IMT of the conus medullaris was suspected. The patient was treated with an 18-month course of antituberculous therapy. The dull ache gradually disappeared, and motor power improved slightly. A follow-up MRI of the lumbosacral (LS) spine revealed that the lesion had completely disappeared. Intramedullary tuberculoma of the conus medullaris should be considered in patients with underlying malignancy and no symptoms of systemic tuberculosis. CSF adenosine deaminase levels can be helpful in determining the presence of central nervous system tuberculosis when other systemic signs of disease are lacking.
\end{abstract}

Keywords: intramedullary tuberculoma; conus medullaris; adenosine deaminase; Froin's syndrome

\section{Introduction}

The most common type of neurotuberculosis is tuberculous meningitis (TBM). Early diagnosis and treatment with chemotherapy and active management of the complications are of great importance to prevent the irreversible neurologic sequel and death. A definite diagnosis of TBM depends on identifying Mycobacterium tuberculosis in the cerebrospinal fluid (CSF) by direct staining or culture. However, the diagnostic yield of CSF smears and cultures has been very low, and mycological cultures may take up to six weeks to yield results [1]. Spinal intramedullary tuberculoma (IMT) is an uncommon disease, with roughly 170 cases having been reported to date. The most common site of involvement is the thoracic cord. The condition occurs in relatively young patients and is often associated with extraspinal tuberculosis disease [2,3]. Intramedullary conus medullaris tuberculoma is extremely rare. Here, we report a case of IMT of the conus medullaris in an elderly man with underlying lymphoma and diabetes. A diagnosis was made based on there being a very high level of adenosine deaminase (ADA) in the patient's cerebrospinal fluid (CSF) and improvement with antituberculous therapy. 


\section{Case Report}

A 78-year-old man presented after having had a dull ache in both thighs for six weeks, and progressive paraparesis for one week. He had a history of diffuse large Bcell lymphoma with symptoms of generalized lymphadenopathy and splenomegaly, for which he had undergone a complete course of chemotherapy (R-CHOP), leading to disease remission two years prior. He also had long term, well-controlled diabetes. General and systemic examinations were normal. Motor power of both lower limbs was $1 / 5$ with an absence of deep tendon reflexes and joint position sense. The remaining of the neurological examination was normal.

Lumbosacral plexopathy was initially diagnosed, caused by infection or lymphoma involvement. A lumbar puncture was performed and xanthochromic CSF was found. Cerebrospinal fluid analysis revealed a white blood cell count of 2 cells $/ \mathrm{mm}^{3}$, a protein concentration of $2181 \mathrm{mg} / \mathrm{dl}$, and a glucose concentration of $57.9 \mathrm{mg} / \mathrm{dl}$ (concurrent a blood glucose concentration of $115 \mathrm{mg} / \mathrm{dl}$ ). Gram stain, Ziehl-Neelsen stain, Indian ink preparation, cryptococcal antigen, and culture were all negative. The CSF culture, which was subsequently reported, was also negative for $M$. tuberculosis. Adenosine deaminase levels in the CSF will help in determining the presence of central nervous system tuberculosis, which was determined by an automated method, were $30.9 \mathrm{U} / \mathrm{L}$. Cytopathological and flow cytometric analysis of the CSF demonstrated no evidence of malignant lymphoma. Due to the patient's high CSF protein concentration but normal cell count (Froin's syndrome), magnetic resonance imaging (MRI) of the lumbo-sacral (LS) spine was performed to rule out a spinal cord compression, and it showed a $4.5 \times 1.5 \mathrm{~cm}$ intramedullary expanding lesion at the T12-L1 level. The lesion was isointense on T1-weighted and hyperintense on T2-weighted and short tau inversion recovery (STIR) images, and exhibited enhanced homogeneously after contrast administration. Diffuse spinal cord edema above the lesion was also detected (Figure 1). The results of a chest X-ray were within the normal limits. Anti-HIV was non-reactive. A T12-L1 laminectomy was performed, revealing an enlarged conus with an irregular surface. The nerve roots appeared normal. A right-side myelotomy and multiple punch out biopsy were performed. Histopathology of the tissues revealed mild reactive gliosis. Neither granuloma nor a tumor was found then Ziehl-Neelsen stain and tissue culture for M.tuberculosis were not performed. After the operation, the patient suffered from urinary retention, which did not resolve.

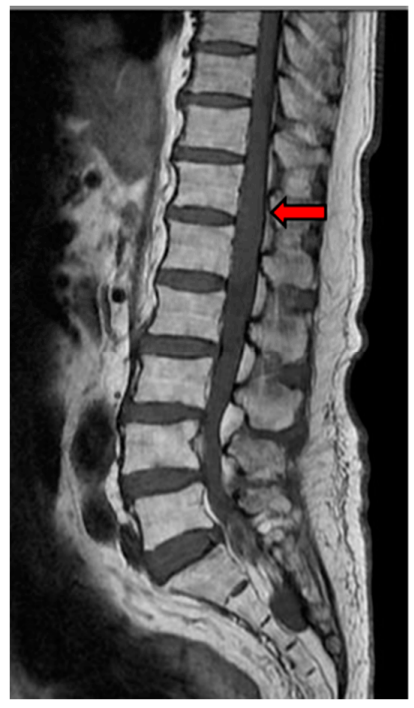

(A) T1WI

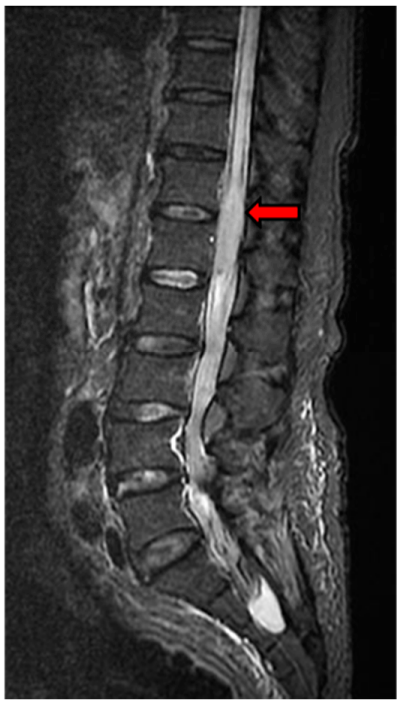

(B) STIR image

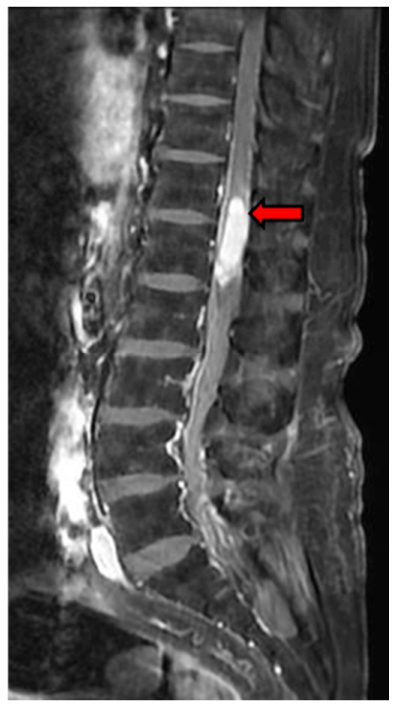

(C) T1WI-FS with Gd

Figure 1. Magnetic resonance imaging of the lumbosacral spine revealed a $4.5 \times 1.5 \mathrm{~cm}$ intramedullary expanding lesion at the T12-L1 level. The lesion exhibited isosignal intensity on the T1-weighted image (A) and hypersignal intensity on the Short tau inversion recovery (STIR) image (B) with homogeneous enhancement (C). Hypersignal intensity of the spinal cord above the lesion was also detected on the STIR image (B), which represented diffuse spinal cord edema. 
Tuberculoma of the conus medullaris was suspected due to the patient having very high CSF-ADA levels [4]. Since Thailand is an endemic area of tuberculosis, we do not routinely use tuberculin skin test or QuantiFERON-TB Gold test for diagnosis of active tuberculous infection. The patient was treated with a combination of antituberculous drugs (isoniazid (I), rifampin (R), pyrazinamide (Z), ethambutol (E)), for two months, followed by IR for eight months, and a six-week course of steroids. The dull ache gradually disappeared, and motor power improved slightly. A follow-up MRI of the LS spine at the 10th month of treatment revealed a marked decreased in the size of the lesion to $0.37 \times 0.53 \mathrm{~cm}$. Treatment with IR drugs was administered for eight more months. The total duration of treatment was, thus, 18 months. A follow-up MRI of the LS spine revealed that the lesion had completely disappeared (Figure 2). At two years follow-up after completion of antituberculous therapy, the motor power of the left leg improved to grade $2-3 / 5$, and the patient has been on permanent suprapubic cystostomy.

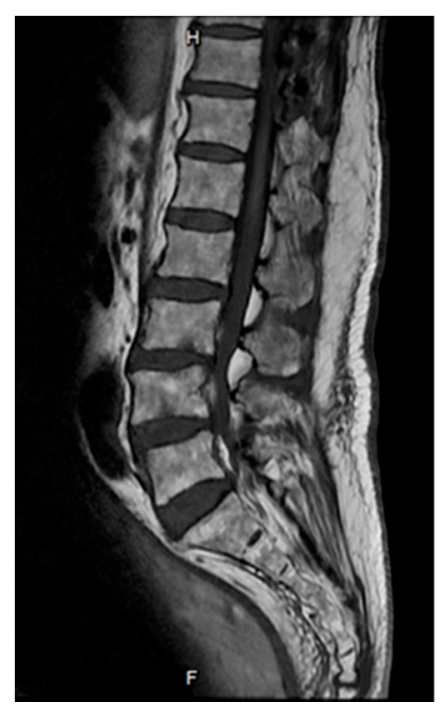

(A) T1WI

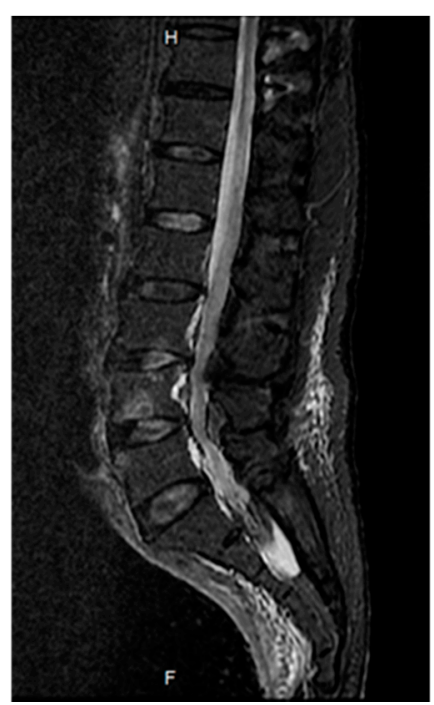

(B) STIR image

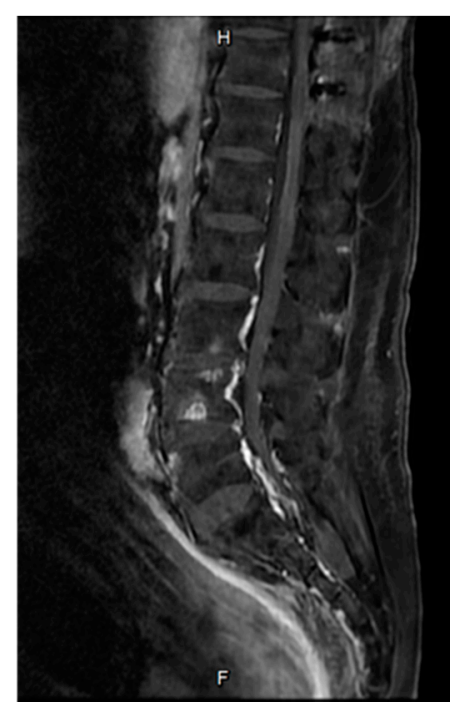

(C) T1WI-FS with Gd

Figure 2. Magnetic resonance imaging of the lumbosacral spine at the 16th month of treatment showing complete resolution of the lesion.

\section{Discussion}

Our patient was less likely to have central nervous system (CNS) relapse of a systemic lymphoma. A review of diffuse large B-cell lymphoma patients with CNS relapse by Villa et al. revealed that the use of R-CHOP appears to reduce the overall risk of CNS relapse, particularly in patients who achieve a complete response. The authors also showed that relapse in the CNS is a serious and most often fatal event. The median survival following CNS relapse (with treatment of CNS relapse) in patients who received the primary therapy with R-CHOP was 3.6 months [5].

Spinal tuberculosis commonly presents as tuberculous spondylitis and arachnoiditis [3]. Isolated without the involvement of overlying bone and meninges is rare, and the most common site of involvement is the thoracic part. Intramedullary tuberculoma of the conus medullaris is extremely rare, and to our knowledge, only about 14 cases have been reported to date in the English literature [6-19]. Table 1 summarized the clinical manifestations and outcomes of these cases, including the present case. Among the 15 cases, there were 12 in which the patients were male (80.0\%). Patients' ages range from 12 to 78 years (mean; 31.9 years), and the duration of symptoms varied from two days to six months. All of the patients had motor weakness of the lower limbs (one or both legs) and most of them had sensory impairment. Other manifestations were urinary symptoms, impotence, and back pain. These clinical presentations are not distinct from those of any other 
intramedullary mass lesion of the conus medullaris [20]. Associated tuberculosis elsewhere in the body was recorded in eight patients (53.3\%). One patient had a history of pulmonary tuberculosis and had undergone antituberculous therapy. One patient developed spinal cord symptoms during treatment of tuberculous meningitis and intracranial tuberculoma, and one patient had had a tuberculous cerebellar abscess 10-months previously. Another two of the patients were HIV positive, and one had a history of lymphoma, which had undergone remission after a course of chemotherapy, and diabetes mellitus. The diagnoses were based on histopathology in eight patients, response to chemotherapy in five patients, lymphocytic CSF with high protein and low glucose level in one patient, and high levels of CSF-ADA in one patient. Surgical excision was performed in six patients (40.0\%). The total duration of antituberculous therapy varied from six to 18 months. Most of the patients exhibited marked improvement after treatment.

Table 1. Clinical features of patients with intramedullary tuberculoma of the conus medullaris.

\begin{tabular}{|c|c|c|c|c|c|c|c|c|}
\hline Author & Age/Sex & $\begin{array}{l}\text { Underlying } \\
\text { Disease }\end{array}$ & $\begin{array}{l}\text { Clinical Presentation and } \\
\text { Duration of Symptoms }\end{array}$ & $\begin{array}{l}\text { Associated } \\
\text { TB }\end{array}$ & $\begin{array}{l}\text { Diagnostic } \\
\text { Method }\end{array}$ & $\begin{array}{l}\text { Surgical } \\
\text { Excision }\end{array}$ & $\begin{array}{c}\text { Duration of } \\
\text { Antituberculous } \\
\text { Treatment }\end{array}$ & $\begin{array}{l}\text { Clinical } \\
\text { Outcome }\end{array}$ \\
\hline $\begin{array}{l}\text { Bradbury et al. } \\
\quad(1980)[6]\end{array}$ & $26 / \mathrm{M}$ & No & $\begin{array}{l}\text { Rt. Leg weakness, } \\
\text { decreased sensation in the } \\
\text { L5-S1 distribution } \\
\text { duration: N/A }\end{array}$ & $\begin{array}{l}\text { Pulmonary } \\
\text { TB }\end{array}$ & $\begin{array}{l}\text { Response to } \\
\text { chemotherapy }\end{array}$ & No & $\mathrm{N} / \mathrm{A}$ & $\begin{array}{l}\text { Complete } \\
\text { recovery }\end{array}$ \\
\hline $\begin{array}{l}\text { Choksey et al. } \\
\text { (1989) [7] }\end{array}$ & $31 / \mathrm{F}$ & No & $\begin{array}{l}\text { Paraparesis, decreased } \\
\text { sensation in the sacral } \\
\text { dermatome, ascending to } \\
\text { the L1-L2 dermatomes, } \\
\text { urgency of micturition } \\
\text { duration: } 4 \text { weeks }\end{array}$ & No & Histopathology & No & $\mathrm{N} / \mathrm{A}$ & $\begin{array}{l}\text { Marked im- } \\
\text { provement }\end{array}$ \\
\hline $\begin{array}{l}\text { Sie et al. (1994) } \\
{[8]}\end{array}$ & $24 / \mathrm{M}$ & No & $\begin{array}{l}\text { Paraparesis, hypoesthesia } \\
\text { in the sacral dermatomes, } \\
\text { urinary urgency, } \\
\text { impotence } \\
\text { duration: N/A }\end{array}$ & No & Histopathology & No & $\mathrm{N} / \mathrm{A}$ & $\begin{array}{l}\text { Marked im- } \\
\text { provement }\end{array}$ \\
\hline $\begin{array}{l}\text { Dehoux et al. } \\
\text { (1996) [9] }\end{array}$ & $58 / \mathrm{M}$ & No & $\begin{array}{c}\text { Fever, headache, } \\
\text { confusion for } 1 \text { month, } \\
\text { followed by back pain and } \\
\text { legs, left hemiparesis, } \\
\text { weakness of the right legs } \\
\text { for } 2 \text { weeks }\end{array}$ & $\begin{array}{l}\text { Tuberculous } \\
\text { meningitis } \\
\text { and cerebral } \\
\text { tubercu- } \\
\text { loma }\end{array}$ & $\begin{array}{l}\text { Lymphocytic } \\
\text { CSF with high } \\
\text { protein and low } \\
\text { glucose level }\end{array}$ & No & $\mathrm{N} / \mathrm{A}$ & $\begin{array}{l}\text { Marked im- } \\
\text { provement }\end{array}$ \\
\hline $\begin{array}{l}\text { Suzer et al. } \\
\text { (1998) [10] }\end{array}$ & $20 / \mathrm{M}$ & No & $\begin{array}{l}\text { Low back pain, urinary } \\
\text { urgency, impotence, distal } \\
\text { weakness of both legs, } \\
\text { hypoesthesia in the sacral } \\
\text { dermatome, ascending to } \\
\text { L4 dermatome } \\
\text { Duration: } 10 \text { days }\end{array}$ & No & Histopathology & Yes & $\mathrm{N} / \mathrm{A}$ & $\begin{array}{l}\text { Marked im- } \\
\text { provement }\end{array}$ \\
\hline $\begin{array}{l}\text { Parmar et al. } \\
\text { (2000) [11] }\end{array}$ & $35 / \mathrm{M}$ & HIV & $\begin{array}{c}\text { Paraparesis } \\
\text { Duration: N/A }\end{array}$ & $\begin{array}{l}\text { Pulmonary } \\
\text { and left } \\
\text { ankle TB }\end{array}$ & $\begin{array}{l}\text { Response to } \\
\text { chemotherapy }\end{array}$ & No & 18 months & improvement \\
\hline $\begin{array}{c}\text { Kemaloglu } \\
\text { et al. }(2001) \\
{[12]}\end{array}$ & $32 / \mathrm{M}$ & No & $\begin{array}{l}\text { Paraparesis and pain, } \\
\text { urinary incontinence } \\
\text { Duration: N/A }\end{array}$ & PulmonaryTB & Histopathology & Yes & 12 months & $\begin{array}{l}\text { Marked im- } \\
\text { provement }\end{array}$ \\
\hline $\begin{array}{l}\text { Tureyen (2002) } \\
{[13]}\end{array}$ & $46 / \mathrm{M}$ & No & $\begin{array}{l}\text { Lt. leg weakness } \\
\text { Duration: } 7 \text { days }\end{array}$ & $\begin{array}{l}\text { History of } \\
\text { Pul- } \\
\text { monaryTB }\end{array}$ & Histopathology & Yes & 6 months & $\begin{array}{l}\text { Complete } \\
\text { recovery }\end{array}$ \\
\hline $\begin{array}{l}\text { Jaiswal et al. } \\
(2006)[14]\end{array}$ & $12 / \mathrm{F}$ & No & $\begin{array}{l}\text { Low back pain, } \\
\text { paraparesis with } \\
\text { numbness, urinary } \\
\text { incontinence } \\
\text { Duration: } 6 \text { weeks }\end{array}$ & No & Histopathology & Yes & $\mathrm{N} / \mathrm{A}$ & $\begin{array}{l}\text { Marked im- } \\
\text { provement }\end{array}$ \\
\hline $\begin{array}{l}\text { Skoglund et al. } \\
\text { (2007) [15] }\end{array}$ & $21 / \mathrm{M}$ & No & $\begin{array}{l}\text { Lumbar pain, sensory } \\
\text { disturbance of both legs } \\
\text { and perianal, lt. leg } \\
\text { weakness, pain during } \\
\text { miction, fever } \\
\text { Duration: } 2 \text { months }\end{array}$ & PulmonaryTB & $\begin{array}{l}\text { Response to } \\
\text { chemotherapy }\end{array}$ & No & 9 months & $\begin{array}{l}\text { Marked im- } \\
\text { provement }\end{array}$ \\
\hline $\begin{array}{l}\text { Maamar et al. } \\
\text { (2007) [16] }\end{array}$ & $22 / \mathrm{M}$ & No & $\begin{array}{l}\text { Paraparesis with } \\
\text { paresthesia, urine } \\
\text { retention, fever } \\
\text { Duration: } 6 \text { months }\end{array}$ & No & Histopathology & Yes & 12 months & $\begin{array}{l}\text { Marked im- } \\
\text { provement }\end{array}$ \\
\hline
\end{tabular}


Table 1. Cont.

\begin{tabular}{|c|c|c|c|c|c|c|c|c|}
\hline Author & Age/Sex & $\begin{array}{l}\text { Underlying } \\
\text { Disease }\end{array}$ & $\begin{array}{l}\text { Clinical Presentation and } \\
\text { Duration of Symptoms }\end{array}$ & $\begin{array}{l}\text { Associated } \\
\text { TB }\end{array}$ & $\begin{array}{l}\text { Diagnostic } \\
\text { Method }\end{array}$ & $\begin{array}{l}\text { Surgical } \\
\text { Excision }\end{array}$ & $\begin{array}{c}\text { Duration of } \\
\text { Antituberculous } \\
\text { Treatment }\end{array}$ & $\begin{array}{l}\text { Clinical } \\
\text { Outcome }\end{array}$ \\
\hline $\begin{array}{l}\text { Lawler et al. } \\
\text { (2013) [17] }\end{array}$ & $12 / F$ & HIV & $\begin{array}{l}\text { Paraparesis with } \\
\text { hyperaesthesia, urinary } \\
\text { retention, febrile } \\
\text { Duration: } 2 \text { days }\end{array}$ & $\begin{array}{l}\text { Cerebellar } \\
\text { abscess TB }\end{array}$ & $\begin{array}{l}\text { Response to } \\
\text { chemotherapy }\end{array}$ & No & $\mathrm{N} / \mathrm{A}$ & $\begin{array}{l}\text { Marked im- } \\
\text { provement }\end{array}$ \\
\hline $\begin{array}{l}\text { Sharoff et al. } \\
\text { (2017) [18] }\end{array}$ & $46 / \mathrm{M}$ & No & $\begin{array}{l}\text { Low back pain, bladder } \\
\text { incontinence, impotence, } \\
\text { paraparesis and } \\
\text { hypoesthesia below L3 } \\
\text { Duration: } 1 \text { month }\end{array}$ & No & Histopathology & Yes & $\mathrm{N} / \mathrm{A}$ & $\begin{array}{l}\text { Complete } \\
\text { recovery }\end{array}$ \\
\hline $\begin{array}{l}\text { Jaiswal et al. } \\
\text { (2017) [19] }\end{array}$ & $16 / \mathrm{M}$ & No & $\begin{array}{l}\text { Back pain, paraparesis, } \\
\text { impaired sensation below } \\
\text { L1, fever } \\
\text { Duration: } 2 \text { weeks }\end{array}$ & $\begin{array}{l}\text { Pulmonary } \\
\text { TB }\end{array}$ & $\begin{array}{l}\text { Response to } \\
\text { chemotherapy }\end{array}$ & No & $\mathrm{N} / \mathrm{A}$ & $\begin{array}{l}\text { Marked im- } \\
\text { provement }\end{array}$ \\
\hline Present case & $78 / \mathrm{M}$ & $\begin{array}{l}\text { Lymphoma, } \\
\text { diabetes } \\
\text { mellitus }\end{array}$ & $\begin{array}{l}\text { Paraparesis with dull ache } \\
\text { Duration: } 6 \text { weeks }\end{array}$ & No & $\begin{array}{l}\text { High level of } \\
\text { CSF-ADA }\end{array}$ & No & 18 months & $\begin{array}{l}\text { Minimal } \\
\text { improve- } \\
\text { ment }\end{array}$ \\
\hline
\end{tabular}

TB: Tuberculosis, CSF: Cerebrospinal fluid, ADA: Adenosine deaminase, N/A: Not available.

Adenosine deaminase (ADA) is an enzyme involved in purine catabolism. It is considered as an indicator of cell-mediated immunity and is found mainly in T lymphocytes [21]. ADA level is also increased in nontuberculous meningitis, but it is marked significantly increased in tuberculous meningitis. So, detection of CSF-ADA activity in the diagnosis of TBM had a relatively high accuracy [22].

In cases such as these, MRI is the optimal method of investigation, as it is both sensitive and noninvasive. The MRI features of IMT can vary depending on the stage of tuberculoma formation (noncaseating, caseating with a solid center, and caseating with a liquid center). In its earliest stage (noncaseating), tuberculoma is characterized by severe inflammatory reaction with poor formation of the collageneous capsule. T1-weighted images show isosignal or slightly hyposignal intensity, and T2-weighted images show hypersignal intensity. The granuloma exhibits homogeneous enhancement after contrast administration on T1-weighted images. Later during the caseating stage, collagen becomes richer in the surrounding capsule, and rim enhancement becomes visible on an MRI after contrast administration. A solid caseating tuberculoma appears iso- to hypointense on T1weighted images and hypointense center with an iso- to hyperintense rim on T2-weighted images. When the solid center of the caseating tuberculoma liquefies, T1-weighted images show hyposignal intensity and T2-weighted images show hypersignal intensity at the center with a hypointense rim [23] However, these findings are not specific to tuberculoma. The differential diagnoses for space-occupying lesions of intramedullary conus medullaris can be based on the presence of spinal intramedullary tumors (astrocytoma, ependymoma, metastasis, lymphoma) and granulomatous inflammations.

A diagnosis of tuberculous infection of the CNS can be based on AFB staining and CSF culture, subacute to chronic lymphocytic CSF with high protein and low glucose levels, histopathological findings, DNA genomic amplification using the polymerase chain reaction (PCR) method, high levels of CSF-ADA, the presence of extraneural tuberculosis foci elsewhere in the body, and responsiveness to antituberculous therapy $[4,24,25]$. In our case, the initial diagnosis was based on extremely high levels of ADA in the patient's CSF.

There is, as of yet, no consensus with regard to the medical and surgical protocols to be employed in the management of spinal IMT. In practice, most researchers recommend antituberculous therapy, with or without corticosteroid, as the initial treatment when IMT is suspected. A combination of four drugs (isoniazid, rifampicin, pyrazinamide, and ethambutol or streptomycin) are administered over a period of two to three months followed by a combination of isoniazid and rifampicin. The total duration of treatment extends from 12 to 18 months. Patients with IMT often recover fully with non-surgical medical treatment alone. Surgery is reserved for cases in which: (1) the diagnosis is uncertain, (2) there is poor response to medical management, (3) there is progressive 
deterioration of neurological deficits during medical treatment, or (4) enlargement of the lesions with mass effect is observed on a follow-up MRI [26,27].

\section{Conclusions}

This is a report of a rare case of intramedullary conus medullaris tuberculoma in an elderly adult with underlying lymphoma and diabetes in which there was an absence of any evidence of systemic TB. CSF adenosine deaminase levels can be helpful in determining the presence of central nervous system tuberculosis when other systemic signs of disease are lacking.

Author Contributions: Conceptualization, V.C. and S.K. methodology, V.C., S.K.; software, W.P.; validation, V.C., C.W. and S.K.; formal analysis, V.C.; investigation, W.P.; resources V.C.; data curation, V.C.; writing—original draft preparation, V.C.; writing—review and editing, V.C, S.K.; visualization, V.C., C.W.; supervision, V.C.; project administration, V.C., W.P.; funding acquisition, S.K. All authors have read and agreed to the published version of the manuscript.

Funding: This research received no external funding.

Institutional Review Board Statement: Ethical approval was provided by the Khon Kaen University Faculty of Medicine Ethics Committee as instituted by the Declaration of Helsinki. HE611264.

Informed Consent Statement: Informed consent was obtained from all subjects involved in the study.

Conflicts of Interest: The authors declare no conflict of interest.

\section{Abbreviations}

IMT: intramedullary tuberculoma; ADA: adenosine deaminase; CSF: cerebrospinal fluid; MRI: magnetic resonance imaging; STIR: short tau inversion recovery; CNS: central nervous system.

\section{References}

1. Chotmongkol, V.; Jitpimolmard, S.; Thavornpitak, Y. Corticosteroid in tuberculous meningitis. J. Med. Assoc. Thai. 1996, 79, 83-90. [PubMed]

2. MacDonell, A.H.; Baird, R.W.; Bronze, M.S. Intramedullary tuberculomas of the spinal cord: Case report and review. Rev. Infect. Dis. 1990, 12, 432-439. [CrossRef] [PubMed]

3. Sharma, M.C.; Arora, R.; Deol, P.S.; Mahapatra, A.K.; Sinha, A.K.; Sarkar, C. Intramedullary tuberculoma of the spinal cord: A series of 10 cases. Clin. Neurol. Neurosurg. 2002, 104, 279-284. [CrossRef]

4. Feres, M.C.; Martino MC, D.; Maldijian, S.; Batista, F.; Gabriel Júnior, A.; Tufik, S. Laboratorial validation of an automated assay for the determination of adenosine deaminase activity in pleural fluid and cerebrospinal fluid. J. Bras Pneumol. 2008, 34, 1033-1039. [CrossRef] [PubMed]

5. Villa, D.; Connors, J.M.; Shenkier, T.N.; Gascoyne, R.D.; Sehn, L.H.; Savage, K.J. Incidence and risk factors for central nervous system relapse in patients with diffuse large B-cell lymphoma: The impact of the addition of rituximab to CHOP chemotherapy. Ann. Oncol. 2010, 21, 1046-1052. [CrossRef]

6. Bradbury, P.G.; Davis, C.J.F. Conus tuberculoma responding to chemotherapy. Ann. Neurol. 1980, 7, 392-393. [CrossRef]

7. Choksey, M.S.; Powell, M.; Gibb, W.R.; Casey, A.T.; Geddes, J.F. A conus tuberculoma mimicking an intramedullary tumor: A case report and review of the literature. Br. J. Neurosurg. 1989, 3, 117-121. [CrossRef]

8. Sie, L.T.; Linssen, W.H. Isolated intramedullary tuberculosis presenting as a conus tumor. Clin. Infect. Dis. 1994, 19, 549-550. [CrossRef]

9. Dehoux, E.; Awada, A.; Palkar, V. Urinary retention revealing a tuberculoma of the conus medullaris in a patient with intracranial tuberculosis: Case report. Spinal Cord 1996, 34, 630-632. [CrossRef]

10. Suzer, T.; Coskun, E.; Tahta, K.; Bayramoğglu, H.; Düzcan, E. Intramedullary spinal tuberculoma presenting as a conus tumor: A case report and review of the literature. Eur. Spine J. 1998, 7, 168-171. [CrossRef]

11. Parmar, H.; Shah, J.; Patkar, D.; Varma, R. Intramedullary tuberculomas. MR findings in seven patients. Acta Radiol. 2000, 41, 572-577. [CrossRef]

12. Kemaloglu, S.; Gur, A.; Nas, K.; Cevik, R.; Buyukbayram, H.; Saraç, A. Intramedullary tuberculoma of the conus medullaris: Case report and review of the literature. Spinal Cord 2001, 39, 498-501. [CrossRef]

13. Tureyen, K. Tuberculoma of the conus medullaris: Case report. Neurosurgery 2002, 50, 651-652.

14. Jaiswal, A.K.; Jaiswal, S.; Gupta, S.K.; Gautam, V.K.S.; Kumar, S. Intramedullary tuberculoma of the conus. J. Clin. Neurosci. 2006, 1, 870-872. [CrossRef] 
15. Skoglund, T.S.; Nilsson, D. Tumor of the conus medullaris treated with antituberculous therapy. Clin. Neurol. Neurosurg. 2007, 109, 192-194. [CrossRef]

16. Maamar, M.; El Quessar, A.; El Fatemi, N.; El Hassani, M.R.; Chakir, N.; Jiddane, M. Intramedullary tuberculoma: A case report. Radiography 2007, 13, 251-254. [CrossRef]

17. Lawler, M.; Zulu, S.; Archary, M.; Govender, V. Intramedullary conus medullaris tuberculoma in an HIV-infected child: An unusual immune reconstitution inflammatory syndrome response. S. Afr. J. Epidemiol. Infect. 2013, 2, 69-71. [CrossRef]

18. Sharoff, L.M.; Unnikrishnan, R.; Jagani, N. Isolated conus medullaris tuberculoma mimicking a tumor: A rare case report. ANZ J. Surg. 2017, 87, E218-E219. [CrossRef]

19. Jaiswal, M.; Gandhi, A.; Purohit, D.; Mittal, R.S. Concurrent multiple intracranial and intramedullary conus tuberculoma: A rare case report. Asian J. Neurosurg. 2017, 12, 331-333. [CrossRef]

20. Ebner, F.H.; Roser, F.; Acioly, M.A.; Schoeber, W.; Tatagiba, M. Intramedullary lesions of the conus medullaris: Differential diagnosis and surgical management. Neurosurg. Rev. 2009, 32, 287-300. [CrossRef]

21. Sullivan, J.L.; Osborne, W.R.; Wedgewood, R.J. Adenosine deaminase activity in lymphocytes. Br. J. Haematol. 1977, 37, 157-158 [CrossRef]

22. Pormohammad, A.; Riahi, S.M.; Nasiri, M.J.; Fallah, F.; Aghazadeh, M.; Doustdar, F.; Pouriran, R. Diagnostic test accuracy of adenosine deaminase for tuberculous meningitis: A systemic review and meta-analysis. J. Infect. 2017, 74, 545-554. [CrossRef]

23. Trivedi, R.; Saksena, S.; Gupta, R.K. Magnetic resonance imaging in central nervous system tuberculosis. Indian J. Radiol. Imaging 2009, 19, 256-265.

24. Perry, M.D.; White, P.L.; Ruddy, M. Potential for use of the Seegene Anyplex MTB/NTM real-time detection assay in a regional reference laboratory. J. Clin. Microbiol. 2014, 52, 1708-1710. [CrossRef]

25. Parny, I.F.; Johnson, E.S.; Allen, P.B. 'Idiopathic' cranial hypertrophic pachymeningitis responsive to antituberculous therapy: Case report. Neurosurgery 1997, 41, 965-971. [CrossRef]

26. Li, H.; You, C.; Yang, Y.; He, M.; Cai, B.; Wang, X.; Ju, Y. Intramedullary spinal tuberculoma: Report of three cases. Surg. Neurol. 2006, 65, 185-188. [CrossRef]

27. Jaiswal, M.; Gandhi, A.; Sharma, A.; Mittal, R.S. Experiences and conceptualization of spinal intramedullary tuberculoma management. Korean J. Spine 2015, 12, 5-11. [CrossRef] 